\title{
Okul Psikolojik Danışma ve Rehberlik Hizmetleri Uygulamalarının Odak Grup Görüșmesi Yöntemi ile Değerlendirilmesi
}

Ömer KARAMAN*

\author{
$\ddot{O} z$
}

Okullarda psikolojik danışma ve rehberlik hizmetleri okul yönetimi, öğretmenler, idari personel, öğrenci ve velilerinin istendik genel ve özel eğitim beklentilerine ile gereksinimlerine göre verilen profesyonel psikolojik yardımlardır. PDR hizmetlerinin geniş kapsamında, hizmetlerin kalitesini etkileyen faktörler olarak mevzuat, okul yönetimleri ve veli tutumları gibi birçok etmen sıralanabilir. Bunların yanı sıra okul PDR hizmetlerini doğrudan yürütenler psikolojik danışmanlardır. Çalışmada okul psikolojik danışmanlarından PDR hizmetlerinin uygulamalarına yönelik odak grup görüşmesi yöntemi ile üç ana başlıkta veri toplanmış ve değerlendirilmiştir. Bunlar okullarda PDR hizmetlerinin etkililiği, karşılaşılan güçlükler ve psikolojik danışmanların konu ile ilgili önerilerini içermektedir. Çalışmada elde edilen verilerin değerlendirilmesinde, okullarda uygulanan PDR hizmetlerinin etkililiği ile ilgili katılımcıların tümü hizmetlerin etkili olarak verilemediğini belirtmiştir. $\mathrm{Bu}$ durumun nedenleri olarak ise zaman yetersizliği, yönetsel, öğretmenler ve velilerle ile ilgili problemler, mevzuat sorunları ve lisans eğitimlerinin yetersizliği bildirilmiştir. Ayrıca karşılaşılan güçlükler tartışılmış ve ilgili öneriler sunulmuştur.

Anahtar Kelimeler: PDR Hizmetleri, Psikolojik Danışmanlar, Odak Grup Görüşmesi

\section{Evaluation of School Counseling and Guidance Services Practices by Focus Group Interview Method}

\begin{abstract}
Psychological counseling and guidance services (PCG) in schools are professional psychological assistance provided according to the general and special education expectations and needs of the school administration, teachers, administrative staff, students and their parents. In the broad scope of PCG services, many factors such as legislation, school management and parent attitudes can be listed as factors affecting the quality of services. In addition to these, psychological counselors and guides are those who directly carry out school PCG services. In the study, data under three main headings were collected and evaluated by focus group interview method for the applications of PCG services from school psychological counselors. These include the effectiveness of PCG services in schools, the difficulties encountered and the recommendations of the psychological counselors on the subject. In the evaluation of the data obtained in the study, all of the participants regarding the effectiveness of PCG services in schools stated that the services could not be provided effectively. Lack of time, administrative problems, problems with teachers and parents, legislative problems and insufficient undergraduate education were reported as the reasons for this situation. In addition, difficulties encountered were discussed and relevant recommendations were presented.
\end{abstract}

Key words: PCG services, psychological counselors, focus group meeting

Geliş/Received: 01.12.2020

Kabul/Accepted: 23.06 .2021

*Bu çalışma deney gerektiren bir çalışma olmayıp bilgi toplamaya yönelik görüşme içermektedir ve katılımcıların onam formu alınarak yapılmıştır. Bu nedenle etik kurul alınmamıştır.

* Doç. Dr. Ordu Üniversitesi Eğitim Fakültesi Eğitim Bilimleri Bölümü Rehberlik ve Psikolojik Danışmanlık Anabilim Dal1. Okaraman44@ hotmail.com ORDIC ID: 0000-0003-1363-7548

(Makale Türü: Araştırma makalesi) 


\section{Giriş}

Psikolojik danışma ve rehberlik (PDR) hizmetleri her yaşta ve her durumda (hastalık, engellilik, mahkumluk vb.) bireylerin kendini tanıması, yeterliliklerinin farkına varması, geliştirmesi ve problemlerini çözebilmesi için yapılan profesyonel desteklerdir. Okullarda psikolojik danışma ve rehberlik hizmetleri ise okul yönetimi, öğretmenler, idari personel, öğrenci ve velilerinin istendik genel ve özel eğitim beklentilerine ve gereksinimlerine göre verilen profesyonel psikolojik yardımlardır. Bu hizmetler psikolojik danışma, oryantasyon, öğrenciyi tanıma, bilgi toplama ve yayma, yöneltme ve yerleştirme ile izlem olarak sıralanabilir.

Okullarda PDR hizmetleri eğitsel, mesleki ve kişisel alanlar olmak üzere üçe ayrılabilir. Eğitsel psikolojik danışma ve rehberlik daha çok öğrenme süreçlerini kapsar. Mesleki psikolojik danışma ve rehberlik meslek seçimi ve uygulama sürecinin yer aldığı kariyer danışmanlığını içerir (Tagay ve Savi Çakar, 2017). Kişisel rehberlik ise bireysel farkındalıklar, gelişim psikolojisi, sosyalleşme, değerler ve grup dinamiği gibi konulara yoğunlaşır. Bu açıdan okul PDR hizmetleri tüm paydaşlar ile birlikte kapsamı oldukça geniş hizmetler bütünü olarak değerlendirilebilir (Tagay ve Savi Çakar, 2017).

PDR hizmetlerinin geniş kapsamında, hizmetlerin kalitesini etkileyen faktörler olarak mevzuat, okul yönetimleri ve veli tutumları gibi birçok etmen sıralanabilir. Bunların yanı sıra psikolojik danışmanlar okul PDR hizmetlerini doğrudan yürütenlerdir. Psikolojik danışmanların verilen hizmette yetkinlikleri ile mesleki başarıları arasında doğrudan ilişki vardır (Lent, Brown ve Hackett, 1994; Schaubroeck, Jones ve Xie, 2001 ve Lu, Siu, ve Cooper, 2005). Yapılan bir çalışmada Türkiye'de psikolojik danışmanların niteliksel olarak yeterli olmadığı verisine ulaşılmıştır (Demirel, 2010). Yine Türkiye'de yapılan bir çalışma da psikolojik danışmanların görevi olmayan işleri yaptıkları ortaöğretim öğrencileri tarafından belirtilmiştir (Duman,1985). Ayrıca farklı başka bir çalışmada da okul psikolojik danışmanların görevlerini tanıtmada yetersiz kaldıkları tespit edilmiştir (Hatunoğlu ve Hatunoğlu, 2006). Benzer araştırmalarda okul psikolojik danışmanların verdikleri hizmetlerin yetersiz olarak değerlendirildiği çalışmalarda mevcuttur (Görkem, 1985; Karagüven, 2001; Hatunoğlu ve Hatunoğlu, 2006). Diğer taraftan okul psikolojik danışmanların karşılaştıkları problemleri belirleyen çalışmalarda 
bulunmaktadır (Parmaksız ve Gök, 2018). Gerçekte okul psikolojik danışmanları okul PDR hizmetlerinin direk uygulayıcıları olarak süreçte yaşanan problemlerin odağında bulunmaktadırlar. $\mathrm{Bu}$ nedenle okul PDR hizmetlerinin kalitesini artırmaya yönelik verilerin toplanarak değerlendirilmesinde, okul psikolojik danışmanlarından elde edilen veriler, önemli olacaktır.

Çalışmada okul psikolojik danışmanlarından odak grup görüşmesi yöntemi ile üç ana başlıkta veri toplanmış ve değerlendirilmiştir. Bunlar okullarda PDR hizmetlerinin etkililiği, karşılaşılan güçlükler ve psikolojik danışmanların konu ile ilgili önerilerini içermektedir. Araştırmada elde edilen veriler doğrultusunda stratejiler belirlemek ve ilgili paydaşlarla sonucu paylaşarak etkili planlamalar yapmak hedeflenmiştir.

Araştırmada nitel araştırma yöntemlerinden odak grup görüşmeleri yöntemi kullanılmıştır. Odak grup görüşmeleri, grup dinamiği süreci ile birlikte, derinlemesine araştırma yapma ve çıkarımlarda bulunma açısından önemlidir $\mathrm{Bu}$ yöntemde bir plan doğrultusunda katılımcılar düşüncelerini serbestçe söyleyerek tartışabilirler Böylece yeni ve farklı fikirler ortaya çıkar (Çokluk ve diğ., 2011). Çalışmada da odak grup görüşme yönteminden faydalanılarak çeşitli okullarda çalışan psikolojik danışmanlardan derinlemesine veri toplamak ve değerlendirmelerde bulunarak PDR hizmetlerinin etkin olarak yürütülmesine yönelik öneriler sunmak planlanmıştır. Çalışma ile literatürde odak grup görüşmeleri yöntemiyle PDR hizmetleri ilk olarak değerlendirilmiştir.

\section{Yöntem}

Çalışmada odak grup görüşmesi yöntemi kullanılmıştır. Odak grup görüşmeleri genel olarak dört aşamada gerçekleştirilir. Çokluk ve arkadaşları (2011), bunları şu şekilde sıralamıştır;

1. Aşama: Araştırma konusunu belirlemek ve konuyu ayrıntılı bir biçimde inceleyerek sınırlarını çizmektedir. Bu incelemede, konular önem sırasına konulmaktadır.

2. Aşama: İkinci aşamada, araştırmaya katılacak kişiler, bu kişilerin özellikleri, kişilerin ortak özellikleri, görüşmede kullanılacak ana başlıklar ve sorulacak sorular belirlenmektedir.

3. Aşama: Bu aşamada, odak grup görüşmesinin yeri, zamanı, moderatör, raportör, varsa diğer görevliler belirlenmekte ve görüşme yapılmaktadır. 
4. Aşama: Görüşme özetlenmekte, raporlar ve kısa notlar incelenmekte, veriler gözden geçirilmekte, görüşmeler analiz edilmekte ve raporlaştırılmaktadır. Bu doğrultuda aşamalarda şu işlemler yapılmıştır;

1. Aşama: Araştırma konusu olarak okullarda PDR hizmetlerinin etkililik durumu seçilmiştir. Buna göre konular önem sırasına göre şu şekilde sıralanmıştır.

- Okulunuzda PDR hizmetlerinin etkililik durumu,

- Okul PDR uygulamalarında karşılaşılan güçlükler,

- Okul PDR hizmetlerinin etkili bir şekilde yürütülmesine yönelik öneriler.

2. Aşama: Araştırmaya çeşitli Ordu ilinde okullarda çalışan 10 psikolojik danışman katılmıştır. Bunlardan ikisi ilkokul, dördü ortaokul ve dördü lisede çalışmaktadır. Odak grup görüşmelerinde katılımcı sayısı ile ilgili farklı görüşler bulunmaktadır. MacIntosh (1981) katılımcı sayısının 6-10 kişi arasında olması gerektiğini belirtirken, Kitzinger'e göre (1995) 4-9 kişi, Gibbs’e göre (1997) 6-12 kişi, Çokluk ve arkadaşlarının (2011) aktardığına göre Edmunds'a göre ise (2000) 8- 10 kişinin katılımcı sayısının yeterli olduğunu bildirmişlerdir. Çalışmada da benzer bir katılımcı sayısının olmasına dikkat edilmiştir. Çalışmaya gönüllü katılım esasında okullarda çalışan psikolojik danışmanlara yer verilmiştir. Katılımcıların bir kısmı birbirlerini tanırken tanımayan psikolojik danışmanlar da bulunmaktadır. Benzer olarak Nelson ve Frontczak (1998) katılımcıların birbirlerini tanımaları veya tanımamalarının önemli olmadığını belirtmişlerdir. Diğer taraftan katılımcılar arasında hiyerarjik ilişki bulunmamaktadır. Yine benzer olarak Kitzinger (1995) grup üyeleri arasında hiyerarjik ilişkinin olmamasına dikkat edilmesi gerektiğini belirtmiştir.

Araştırmanın iki ısındırma sorusu üç ana tema sorusu bulunmaktadır. Bunlar;

\section{Isındırma Soruları}

1- Okullarda genellikle hangi öğrenci problemleri ile karşılaşıyorsunuz?

2- Okul PDR hizmetlerinde Rehberlik ve Araştırma Merkezinin (RAM) yeri nasıl olmalidır? 


\section{Tema Merkezli Sorular}

3- Okulunuzda PDR hizmetleri etkili olarak uygulanabiliyor mu?

4- Okul PDR uygulamalarında karşılaşılan güçlükler nelerdir?

5- Okul PDR hizmetlerinin etkili bir şekilde yürütülmesine yönelik önerileriniz nelerdir?

Kitzinger (1995) ve Gibbs (1997) de odak grup görüşmelerinde bir veya iki sorunun tema dışında 1sındırma sorusu olması gerektiğini sonra tema merkezli sorulara geçilmesi gerektiğini bildirmişlerdir.

3. Aşama: Odak grup görüşmesi bir ortaokulun hizmet içi eğitim salonunda yapılmıştır. Moderatör olarak araştırmacı görev alırken, raportör olarak ise araştırmadan bağımsız başka bir uzman çalışmıştır.

4. Aşama: Çalışmada elde edilen veriler analiz edilerek, değerlendirilmiştir.

\section{İșlem}

Odak grup görüşmesinin uygulama süreci Kitzinger (1995), Gibbs (1997) ve Çokluk ve arkadaşlarının (2011) görüşleri doğrultusunda şu sıra ile gerçekleştirilmiştir;

1. Kullanılacak materyaller çalışma yapılmadan önce çalışmanın yapılacağı yere getirilerek, kontrol edilmiştir.

2. Moderatör ve raportör ile diğer katılımcılara yaka kartları hazırlanarak dağıtılmıştır.

3. Görüşme odasının kapısına rahatsız edilmemesine yönelik uyarı yazısı yapıştırılmıştır.

4. Yuvarlak biçimde, kolsuz sandalyeler oturma düzenini oluşturmuştur.

5. Moderatör ve rapartör kendini kısaca tanıtmış ve diğer grup üyelerinin kendilerini tanıtmaları istenmiştir.

6. Moderatör tarafından görüşmenin amacı, elde edilen bilgilerin taraflarının gizliliği, süreç ve zaman açıklanmıştır.

7. Isındırma soruları ve görüşme soruları açık uçlu olarak gruba yönlendirilmiş ve derinlemesine sorularla desteklenmiştir. Tüm katılımcılara söz hakkı verilmiştir.

8. Değinilmeyen bir konu veya eklenmek istenen konu ile ilgili görüşler final sorusu ile tamamlanmıştır.

9. Odak grup görüşmesi 1,5 saat içerisinde sonlandırılmıştır. 


\section{Verilerin Analizi}

Verilerin analizinde nitel araştırma yöntem kullanılmış (Britten, 1995; Mays ve Pope, 1995), genelleme yapılmayarak sayısallaştırmaya gidilmemiş ve içerik analizi kullanılmıştır. Verilerin çözümlenmesinde katılımcıların söylemlerine göre anahtar temalar belirlenmiştir (Okluk ve diğ., 2011).

\section{Bulgular}

Araştırmanın tema merkezli soruları şunlardır;

1- Okulunuzda PDR hizmetleri etkili olarak uygulanabiliyor mu?

2- Okul PDR uygulamalarında karşılaşılan güçlükler nelerdir?

3- Okul PDR hizmetlerinin etkili bir şekilde yürütülmesine yönelik önerileriniz nelerdir?

$\mathrm{Bu}$ doğrultuda okullarda uygulanan PDR hizmetlerinin etkililiği ile ilgili yapılan görüşmede katılımcıların tümü hizmetlerin etkili olarak verilemediğini belirtmiştir. Bunun üzerine yapılan sonda sorularda şu verilere ulaşılmıştır;

- Psikolojik danışma ve rehberlik hizmetlerinin aktif olarak uygulanması için okul saatlerinde (ilkokullar hariç) yeterli saatin ayrılmaması,

- Somut bir yönetmeliğin ve mevzuatın olmaması,

- PDR hizmetleri dışında görevlerin verilmesi,

- Okul yönetiminden kaynaklı problemlerin yaşanması,

-Uzun süren olumsuz sürecin psikolojik danışmanlarda değersizlik oluşturması nedeni ile tükenmişlik yaşanması.

- PDR lisans eğitimlerinin yetersiz olması nedeni ile spesifik konularda etkin hizmet verilememesi, bu doğrultuda yapılan hizmetiçi eğitimlerin uygulamaya yönelik etkili olmaması.

Çalışmanın ikinci temasını oluşturan okul PDR uygulamalarında karşılaşılan güçlükler ile ilgili şu verilere ulaşılmıştır;

- Öğretmenlerin bahane bulmaları, direnç göstermeleri,

- Okul yönetimlerinin bireysel çıkarları doğrultusunda engellemeler ve dayatmalar yapmas1, 
- Velilerin sürece olumsuz şekilde dahil olmaları, evhamlı ve aşırı hassasiyet göstermeleri.

Çalışmanın üçüncü temasını oluşturan okul PDR hizmetlerinin etkin olarak yürütülmesine yönelik öneriler ile ilgili ise şu verilere ulaşılmıştır;

- Okul PDR hizmetlerinin etkin olarak uygulanmasına yönelik lisans eğitimlerinin verilmesi ve etkili hizmetiçi eğitimlerle desteklenmesi,

- Görev ve unvanların netleştirildiği bir yönetmeliğin oluşturulması,

- Okul yönetimleri ile PDR servislerinin çalışma düzeneğinin daha profesyonel yapıya dönüşmesi için gerekli mevzuat değişikliklerinin yapılması.

\section{Tartışma}

Çalışmada okullarda uygulanan PDR hizmetlerinin etkililiği ile ilgili yapılan görüşmede katılımcıların tümü hizmetlerin etkili olarak verilemediğini belirtmiştir. Benzer olarak yapılan bir çalışmada da PDR hizmetlerinin yaklaşık \%56 düzeyinde verildiği tespit edilmiştir (Yüksel Şahin, 2008). Farklı olarak okul yönetimlerinin PDR hizmetlerini değerlendirdiği Amerika Birleşik Devletleri’nde (ABD) yapılan bir araştırmada ise memnuniyet düzeyi \%92 bulunmuştur (Zalaquett, 2005). Yine ABD’de yapılan başka bir çalışmada okul yöneticilerinin \%73'ü PDR hizmetlerinden memnun olduklarını bildirmişlerdir (Beesley ve Frey,2006). Bu durum ABD'de PDR hizmetlerinin etkin bir şekilde yürütülmesinde kolaylaştırıcı faktörlerin (eleman, malzeme, zaman yeterlilikleri vb.) sağlanmasına bağlanabilir. PDR hizmetlerinin etkin olarak yürütülmemesinin nedenleri ve ilgili değerlendirmeler şöyledir;

- Psikolojik danışma ve rehberlik hizmetlerinin aktif olarak uygulanması için okul saatlerinde (ilkokullar hariç) yeterli saatin ayrılmaması verisine ulaşılmıştır. Benzer olarak Hatunoğlu (2006), ErdurBaker ve Çetinkaya (2007) ve (Kız1l,2007) yaptıkları araştırmalarda rehberlik saati zamanının sınırlılığı ile ilgili problemler yaşandığını tespit etmişlerdir. $\mathrm{Bu}$ durum okullarda etkin PDR hizmetlerinin uygulanmasında zaman yetersizliğinin önemli bir faktör olduğunu göstermektedir.

- Somut bir yönetmeliğin ve mevzuatın olmaması ise diğer ulaşılan veridir. Benzer olarak görev tanımlarının somut olarak açıklanmamasından kaynaklı problemlerin yaşandığı çeşitli araştırmalarda tespit edilmiştir (Özer, 1998; Hamamcı, Murat ve Çoban,2004; Tuzgöl-Dost ve Keklik, 2012) 
- Okullarda psikolojik danışmanlara PDR hizmetleri dışında görevlerin verildiği tespit edilmiştir. Benzer olarak okullarda psikolojik danışmanların görevleri dışında işe zorlandıkları, idari işlerde görevlendirildikleri, boş derslere girmeleri istendiği ve çeşitli görevleri olamayan isteklerde bulunulduklarına dair verilerin olduğu araştırmalar mevcuttur (Güven,2003; Hamamc1, Murat ve Çoban, 2004; Yüksel Şahin, 2008; Tagay ve Savi Çakar,2017). Son çıkarılan 14 Ağustos 2020 tarihli Psikolojik Danışma ve Rehberlik Hizmetleri Yönetmeliği'nin 21.Maddesinde psikolojik danışmanın görevleri açıklanmış olup okul yönetimlerinin PDR hizmetleri dışında görev veremeyecekleri belirlenmiştir. $\mathrm{Bu}$ doğrultuda psikolojik danışmanların okul PDR hizmetleri dışında görevleri kabul etmemeleri ve aksi durumlarda yasal haklarını savunmaları beklenmektedir.

- Araştırmanın diğer bulgusu da okul PDR hizmetlerinin yürütülme sürecinde okul yönetiminden kaynaklı problemlerin yaşanmasıdır. Benzer olarak yöneticilerin çok yüksek beklenti içerisinde olmaları Yüksel-Şahin (2008), PDR hizmetlerine yeterince destek olmamaları (Hamamcı, Murat ve Çoban, 2004), ilgisiz ve isteksiz olmaları, PDR hizmetlerinin amacını bilmemeleri (Nazl1,2007),ön yargılı tutum sergilemeleri (TuzgölDost ve Keklik 2012), ve görev tanımlarını bilmemeleri verilerine ulaşılmış olan çalışmalarda bulunmaktadır. Bu durum okul yönetimlerinin PDR hizmetleri açısından önemli bir problem kaynağı olduğunu göstermektedir.

- Araştırmada iş yaşamlarında uzun süren olumsuz sürecin psikolojik danışmanlarda değersizlik oluşturması nedeni ile tükenmişlik yaşanması, verisine ulaşılmıştır. Benzer olarak Rayle (2006) yaptığı çalışmada psikolojik danışmanların iş stres düzeylerini yüksek mesleki doyumlarını ise düşük bulmuştur. Yine Akten (2007) çalışma koşullarının psikolojik danışmanlarda tükenmişlik duygusuna neden olduğunu bildirmiştir. Özer (1998) ise Türkiye genelini kapsayan çalışmasında psikolojik danışmanlarda duygusal tükenme, kişisel başarısızlık ve duyarsızlaşma saptamıştır. Diğer taraftan okul psikolojik danışmanlarda kişisel başarısızlık ile birlikte duyarsızlaşma ve tükenmişlik (Seğmenli, 2001, Çoban ve Demir, 2004) ve psikolojik danışman özellikleriyle (dışadönük, iletişim kurabilen, kendi ile barışık) tükenmişlik düzeyleri verileri arasında ters ilişki (Özabacı, İşmen ve Yıldız, 2004) verilerine ulaşılmıştır. Bu 
durum geçmişten günümüze kadar olan tarihsel süreçte psikolojik danışmanların iş yaşam doyumlarının düşük ve tükenmişlik düzeylerinin genellikle yüksek olduğu şeklinde açıklanabilir. Gerçekte psikolojik danışmanların danışanlarla kurduğu duygusal ilişki tükenmişliğe zemin hazırlar (Watkins, 1983) ve bundan kaçınmak oldukça zordur (İkiz, 2010). PDR hizmetleri sürecinde aşırı özdeşim kurmak veya duyarsızlaşmak da objektifliği kaybettirmekte önemli bir faktör oluşturmakta ve danışmanı duygusal tükenmişliğe itmektedir (İkiz, 2010). Aynı zamanda çok sayıda görüşme ve bunların çoğunluğunun benzer olmaları da psikolojik danışmanların tükenmişlik yaşamaları için faktör oluşturmaktadır (Milburn, 1981).

- Araştırmada PDR lisans eğitimlerinin yetersiz olması nedeni ile spesifik konularda etkin hizmet verilememesi, bu doğrultuda yapılan hizmetiçi eğitimlerin uygulamaya yönelik etkili olmamasından dolayı PDR hizmetlerinin etkin yürütülmesini olumsuz etkilediği belirlenmiştir. Benzer olarak yapılan bir çalışmada PDR lisans eğitimi derslerinin kuram ağırlıklı yürütüldüğü, ders sayısı ve çeşitliliğinin az olduğu ve uygulama ile paralellik göstermediği verilerine ulaşılmıştır Yerin, Güneri, BüyükgözeKavas ve Koydemir (2007). Yine Tuzgöl-Dost ve Keklik (2012) tarafindan yapılan çalışmada da lisans eğitimi yetersiz bulunmuş ve uygulamalar ile özel eğitim, psikolojik testler, Milli Eğitim Bakanlığı sistemi, resmi işlemler ve yazışmalar, psikolojik danışma kuramları konularının eksik verildiği değerlendirmesi yapılmıştır. Doğan ve Erkan (2001) yaptıkları araştırmada lisan programlarının ders çeşitliliği, sayısı, öğretim elemanı eksiklikleri ve nitelikleri ile ilgili problemlerin olduğu verilerini paylaşmıştır.

Çalışmanın ikinci temasını oluşturan okul PDR uygulamalarında karşılaşılan güçlükler ile ilgili değerlendirme ise şöyledir;

- Odak grup görüşmesinde psikolojik danışmanlar öğretmenlerin bahane bulduklarını ve direnç gösterdiklerini belirtmişlerdir. Benzer olarak yapılan çalışmalarda öğretmenlerin yeterince psikolojik danışmanlara destek vermediği (Hamamc1, Murat ve Çoban, 2004), rehberlik hizmetlerine karşı olumsuz bakışlarının olduğu (Hatunoğlu, 2006), çalışmalara katılmada isteksiz davrandıkları ve yine ilgisizlik-isteksizliğin yanı sıra yanlış tutumlar sergiledikleri sonuçlarına varılmıştır (Parmaksız ve Gök, 2018; Tagay ve Savi Çakar, 2017).

-PDR hizmetlerinin etkin yürütülmesinde karşılaşılan diğer faktör ise okul yönetimlerinin bireysel çıkarları doğrultusunda engellemeler ve dayatmalar yapmasıdır. 
Benzer olarak yapılan çalışmalarda psikolojik danışmanların görevleri dışında işlere zorlandıkları (Hamamcı, Murat ve Çoban, 2004; Hatunoğlu 2006) ve yapabileceklerinin üzerinde çalışmalar beklendiği (Altun ve Camadan, 2013) bilgilerine ulaşılmıştır.

- Velilerin sürece olumsuz şekilde dahil olmaları, evhamlı ve aşırı hassasiyet göstermeleri ise diğer bir faktör olarak belirlenmiştir. Benzer olarak yapılan çalışmalarda velilerin ilgisizliği, iş birliğine girmemeleri yanı sıra normal dışı beklentiler, sonuçları bildirilmiştir (Tagay ve Çakar, 2017; Parmaksız ve Gök, 2018; Tuzgöl-Dost ve Keklik,2012; Karataş ve Şahin-Baltac1,2013).

Çalışmanın üçüncü temasını oluşturan okul PDR hizmetlerinin etkin olarak yürütülmesine yönelik öneriler ile ilgili verilerin değerlendirmesi de şöyledir;

- Okul PDR hizmetlerinin etkin olarak uygulanmasına yönelik lisans eğitimlerinin verilmesi ve etkili hizmetiçi eğitimlerle desteklenmesi,

- Görev ve unvanların netleştirildiği bir yönetmeliğin oluşturulması, 14 Ağustos 2020 tarihli Psikolojik Danışma ve Rehberlik Hizmetleri Yönetmeliği ile görev ve unvanlar netleştirilmiştir.

- Okul yönetimleri ile PDR servislerinin çalışma düzeneğinin daha profesyonel yapıya dönüşmesi için gerekli mevzuat değişikliklerinin yapılması istenmiştir. PDR hizmetlerinin ve çalışanlarının daha özerk bir yapı ile çalışmasına yönelik öneriler henüz tam olarak gerçekleşmemiştir.

\section{Sonuç ve Öneriler}

$\mathrm{Bu}$ aşamada elde edilen sonuçlara göre öneriler sunulmuştur. Buna göre;

- Psikolojik danışma ve rehberlik hizmetlerinin aktif olarak uygulanması için okul saatlerinde (ilkokullar hariç) yeterli saatin ayrılmasına yönelik tedbirler alınmalıdır. Bu doğrultuda her öğretim kademesi (okul öncesi, ilkokul, ortaokul ve lise) için ayrılacak uygun süre Türk PDR Derneği ile yapılacak bir çalışmada bulunabilir ve pilot uygulamalardan sonra verimli bir süreç yakalanabilir.

- Somut bir yönetmelik14 Ağustos 2020 tarihli Psikolojik Danışma ve Rehberlik Hizmetleri Yönetmeliği ile oluşturulmuştur. Böylece okullarda psikolojik danışmanlara PDR hizmetleri dişında görevlerin verilmesinin önüne geçilmeye çalışılmıştır. Söz konusu yönetmeliğin sahada nasıl uygulandığı ve sonuçları izlenmelidir. 
• Okul PDR hizmetlerinin yürütülme sürecinde okul yönetiminden kaynaklı problemlerin yaşanmamasına yönelik gerekli yönetsel ve mevzuat değişiklikleri ile birlikte okul yönetimlerine etkili denetim ve hizmetiçi eğitimler yapılmalıdır.

- İş yaşamlarında uzun süren olumsuz sürecin psikolojik danışmanlarda değersizlik oluşturması nedeni ile tükenmişlik yaşanmaması için süpervizyon eğitimlerinin artırılması gerekmektedir. Ayrıca meslek dayanışmasına yönelik gerek PDR Derneği gerek RAM müdürlüklerince destek çalışmalarının yapılması uygun olacaktır.

-PDR lisans eğitimlerinin uygulama ağırlıklı ve yeterli kalitede yapılması gerekmektedir. Bu doğrultuda PDR lisans eğitimlerinin akredite çalışmalarının tüm PDR lisanlarını kapsayacak şekilde yaygınlaştırılması gerekmektedir.

- Öğretmenlerin PDR çalışmalarında bahane bulmamaları ve direnç göstermemeleri için hizmetiçi eğitimler ve denetimler yapılmalıdır.

-Velilerin PDR hizmetlerine olumlu şekilde dahil olmaları için anne-baba eğitim programları düzenlemelidir. Ayrıca velilere okul web sayfalarında düzenli olarak ulaşılmalı ve veli bültenleri ile desteklenmelidir.

Teşekkür: Çalışmaya katılan Ordu ili Altınordu ilçesi Psikolojik Danışmanlarına ve Roportör olarak çalışan Uzm Bilge TARIM'a katkılarından dolayı teşekkür ederim.

\section{Kaynakça}

Akten, S. (2007). Rehber Öğretmenlerin Mesleki Tükenmişlik Düzeylerinin İncelenmesi (Yüksek Lisans Tezi), Trakya Üniversitesi Sosyal Bilimler Enstitüsü Eğitim Bilimleri Anabilim Dalı, Edirne.

Altun, T. ve Camadan, F. (2013). Rehber öğretmenlerin rehber öğretmen (psikolojik danışman) kavramına ilişkin algılarının metafor analizi yoluyla incelenmesi. Kastamonu Eğitim Dergisi, 21 (3), 883-918.

Beesley, D. ve Frey, L. L. (2006). Principals' perceptions of school counselor roles and satisfaction with school counseling services. Journal of School Counseling, 4(14), 27-39.

Britten, N. (1995). "Qualitative interviews in medical research", British Medical Journal, $311,251-253$.

Çoban, A. E. ve Demir. A. (2004) Güneydoğu Anadolu bölgesinde görev yapan psikolojik danışmanların tükenmişlik düzeyleri ve bazı demografik değişkenlerle tükenmişlik arasındaki ilişkinin incelenmesi, Çukurova Üniversitesi Eğitim Fakültesi Dergisi, 2(28), 20-28.

Çokluk, Ö. Yılmaz, K. Oğuz, E. (2011) Nitel Bir Görüşme Yöntemi: Odak Grup Görüşmesi. Kuramsal Eğitim bilim, 4 (1), 95-107. 
Demirel, M. (2010). İlköğretim ve ortaöğretim kurumları sınıf rehberlik programının değerlendirilmesi. Eğitim ve Bilim, 35(156), 45-60.

Doğan, S. ve Erkan, S. (2001). Türkiye'de Psikolojik Danışman Eğitimi Profili: Mevcut Durum, Sorunlar ve Çözüm Önerileri. VI. Ulusal Psikolojik Danışma ve Rehberlik Kongresi. Ankara: ODTÜ Eğitim Fakültesi.

Duman, E. (1985). Lise Öğrencilerinin Rehberlik Uzmanlarından Görev Beklentileri ve Görev Beklentilerine Etki Eden Faktörler (Bilim Uzmanlığı Tezi). Hacettepe Üniversitesi, Sosyal Bilimler Enstitüsü, Ankara

Erdur-Baker, Ö. ve Çetinkaya, E. (2007). Etik: davranışta kırılma noktası. İçinde Özyürek,R., F. KorkutOwen ve D. Owen (Ed.), Gelişen psikolojik danışma ve rehberlik, meslekleşme sürecinde ilerlemeler, (ss. 163-182), Cilt 1. Ankara: Nobel Yayin.

Gibbs, A. (1997). Focus groups. Social Research Update, 19. Erişim adresi: http://sru.soc.surrey.ac.uk/SRU19.html. İndirme Tarihi: 03.11.2020.

Görkem, N. (1985). Öğrencilerin Rehberlik Uzmanlarından Gördükleri Hizmetlerle Bekledikleri Hizmetler Arasındaki Fark (Yüksek Lisans Tezi). Ankara Üniversitesi, Sosyal Bilimler Enstitüsü, Ankara.

Güven, M. (2003). Psikolojik Danışmanların Okul Yöneticileri İle İlişkilerinin Değerlendirmesi VII. Ulusal Psikolojik Danışma ve Rehberlik Kongresi Bildiri Özetleri Kitabı (s. 102). Ankara: Türk PDR Derneği Yayını.

Hamamc1, Z. Murat, M. Çoban, A.E. (2004). Gaziantep" teki okullarda çalışan psikolojik danışmanların mesleki sorunlarının incelenmesi. 13. Ulusal Eğitim Bilimleri Kurultayı, İnönü Üniversitesi, Malatya.

Hatunoğlu, Y.ve Hatunoğlu, Y. (2006). Okullarda verilen rehberlik hizmetlerinin problem alanları. Kastamonu Eğitim Dergisi, 14(1), 333-338.

İkiz, F. E. (2010). Psikolojik Danışmanların Tükenmişlik Düzeylerinin İncelenmesi. Ahi Evran Üniversitesi Eğitim Fakültesi Dergisi, 11(2),25-43.

Karagüven, H. (2001). Endüstri Meslek Liselerinde Rehberlik Servislerinin İşlerliğinin İncelenmesi ve Gereksinim Belirleme Çalışması. VI. Ulusal Psikolojik Danışma ve Rehberlik Kongresi. Ankara: ODTÜ Eğitim Fakültesi.

Karataş, Z. ve Şahin, Baltacı, H. (2013). Ortaöğretim kurumlarında yürütülen psikolojik danışma ve rehberlik hizmetlerine yönelik okul müdürü, sınıf rehber öğretmeni, öğrenci ve okul rehber öğretmeninin (psikolojik danışman) görüşlerinin incelenmesi. Ahi Evran Üniversitesi Kırşehir Eğitim Fakültesi Dergisi (KEFAD), $\quad$ 14(2), 427-460

Kızıl, D. (2007). Ortaöğretim kurumlarındaki rehber öğretmenlerin ve sınıf rehber öğretmenlerin sınıf içi rehberlik etkinlikleri ile ilgili görüşleri. (Yüksek Lisans Tezi).

Selçuk Üniversitesi Sosyal Bilimler Enstitüsü, Konya.

Kitzinger, J. (1994). The methodology of focus groups: the importance of interaction between research participants, Sociology of Health and Illness, 16 (1), 103-121.

Kitzinger, J. (1995). Qualitative research: introducing focus groups, British Medical Journal, 311, 299-302. 
Lent, R. W. Brown, S.D. Hackett, G. (1994). Toward a unifying social cognitive theory of career and academic interest, choice, and performance. Journal of Vocational Behavior, 45, 79-122.

Lu, C. Siu, O. ve Cooper, C.L. (2005). Managers' occupational stress in China the role of self efficacy. Personality \& Individual Differences, 38 (3), 569-579.

MacIntosh, J. (1981). Focus groups in distance nursing education, Journal of Advanced Nursing, 18 (12), 1981-1985.

Mays, N. \& Pope, C. (1995). Rigour and qualitative research, British Medical Journal, 311, $109-112$.

Milburn, B.M. (1981). Burnout. Personnel and Guidance Journal.59.484.

Millî Eğitim Bakanlığı Rehberlik ve Psikolojik Danışma Hizmetleri Yönetmeliği, Resmi Gazete, 14 Ağustos 2020sayı:31213 Erişim adresi: https://www.resmigazete.gov.tr/eskiler/2020/08/20200814.pdf

Nazlı, S. (2007). Okul Yöneticilerinin Rehberlik ve Psikolojik Danışma Hizmetlerini Algılamaları. Eğitim Araştırmaları Dergisi, 26, 155-166.

Nelson, J.E. ve Frontczak, N.T. (1998). How acquaintanceship and analyst can influence focus group results, Journal of Advertising, 17 (1), 41-48.

Özabacı, N. İşmen, A. E. Yıldız, S.A. (2004). Psikolojik Danışmanların İdeal Özellikleri ile Yılgınlık Düzeylerinin Karşılaştırması. Kuram ve Uygulamada Eğitim Yönetimi, 10(37):8-25.

Özer, R. (1998). Rehber öğretmenlerde tükenmişlik düzeyi, nedenleri ve çeşitli değişkenlere göre incelenmesi (Yüksek Lisans Tezi). Karadeniz Teknik Üniversitesi, Sosyal Bilimler Enstitüsü, Trabzon.

Parmaksız İ, Gök A. (2018). Okul Psikolojik Danışmanlarının Psikolojik Danışma ve Rehberlik Hizmetlerinin Yürütülmesinde Karşılaştıkları güçlükler. Mehmet Akif Ersoy Üniversitesi Eğitim Fakültesi Dergisi, 47,247-265.

Rayle, A. D. (2006). Do School Counselors Matter? Mattering As a Moderator Between Job Stress and Job Satisfaction. Professional School Counseling, 9 (3), 206-215.

Schaubroeck, J. Jones, J.R. ve Xie, J.L. (2001). Individual differences in utilizing control to cope with job demands: Effects on susceptibility to infectious disease. Journal of Applied Psychology, 86 (2), 265-278.

Seğmenli, S. (2001). Rehber öğretmenlerin tükenmişlik düzeylerinin incelenmesi. (Yüksek Lisans Tezi). Hacettepe Üniversitesi, Sosyal Bilimler Enstitüsü, Ankara.

Tagay, Ö. ve Savi Çakar, F. (2017). Okullarda Yürütülen Psikolojik Danışma ve Rehberlik Hizmetlerine İlişkin Okul Psikolojik Danışmanlarının Görüşleri. KEFAD 18(3),1168-1186.

Tuzgöl-Dost, M. ve Keklik, İ. (2012). Alanda çalışanların gözünden psikolojik danışma ve rehberlik alanının sorunları. Mehmet Akif Ersoy Üniversitesi Eğitim Fakültesi Dergisi, 23, 389-407.

Watkins, C. E. (1983). Burnout in counseling practice: some potential professional amd personal hazards of becoming a counselor. The Personel And Guidance Journal. January. 304-308.

Yerin Güneri, O, Büyükgöze Kavas, A. Koydemir, S. (2007). Okul psikolojik danışmanlarının profesyonel gelişimi: Acemilikten olgunlaşmaya giden zorlu yol. İçinde R. Özyürek, F. Korkut Owen ve D. W. Owen (Ed.), Gelişen psikolojik 
danışma ve rehberlik, meslekleşme sürecinde ilerlemeler, (ss.139-160), Cilt 1. Ankara: Nobel Yayıncilik.

Yüksel-Şahin F. (2008). Ortaöğretimdeki öğrenci görüşlerine göre Psikolojik Danışma ve Rehberlik (PDR) hizmetlerinin değerlendirilmesi. Uluslararası İnsan Bilimleri Dergisi. 5(2), 1-26.

Zalaquett, C. P. (2005). Principals' perceptions of elementary school counselors' role and functions. Professional School Counseling, 8, 451-457. 